\title{
Ligita JUDICKAITĖ-PAŠVENSKIENE்
}

Vytautas Magnus University

\section{SUBTITLED CARTOONS IN FOREIGN LANGUAGE TEACHING AND LEARNING CONTEXT: POSSIBLE DANGERS}

Summary. Foreign language teaching and learning has evolved into a multiple process which includes not only the printed and audio, but also visual, audiovisual, subtitled audiovisual and other types of material. Many researches show that subtitled audiovisual material as well as the very process of subtitling is beneficial in various foreign language teaching and learning contexts.

The aims of the article are as follows: to introduce subtitling and its use for language teaching and learning as well as to discuss possible dangers of the use of interlingual subtitles (i.e. dialogues in one language are presented in the form of subtitles in another language) of children's cartoons in the context of incidental language acquisition in Lithuania. The descriptive comparative analysis of seven children's cartoons concentrates on the English language learning issues related with translation of idioms from English into Lithuanian, general translation problems, subtitle segmentation and breaking.

The results of the study show that not all idiomatic source language expressions retain their idiomatic aspect in the Lithuanian subtitles, even in the cases when such retention is possible; cases of inaccurate translation as well as errors in segmentation and line breaking are noted. All of these may impoverish the children's mother tongue and diminish the process of foreign language acquisition.

Keywords: subtitles, cartoons, foreign language teaching and learning, idioms.

\section{Introduction}

In today's rapidly developing world foreign language learning and teaching has moved far away from the use of the blackboard and the chalk only. Now learners have opportunities to enjoy computer assisted language learning, language learning via subtitling, incidental language learning while watching audiovisual material, etc. The use of subtitled audiovisual material in both foreign language classroom and incidental learning situations has received a lot of attention from researchers; despite some doubts, most of the studies cannot refute the fact that such material is a powerful tool for foreign language acquisition. In Lithuania, however, the topic of subtitles in language learning is virtually unexplored, except for the project Subtitrai ir kalbu mokymasis, in 
which nine European countries, including Lithuania, have taken part (http:// www.sublanglearn.utu.fi/).

The aim of the present article is twofold: to introduce subtitling and its use for language teaching and learning as well as to discuss the dangers of the use of interlingual subtitles (i.e. dialogues in one language are presented in the form of subtitles in another language) of children's cartoons in the context of incidental language acquisition in Lithuania. The latter argument is based on the analysis of seven children's cartoons which are on release in the UK or the USA and which are subtitled into Lithuanian: Valiant (2005), The Wild (2006), Over the Hedge (2006), Ratatouille (2007), Bee Movie (2007), Horton Hears a Who (2008), and Rio (2011). The cartoons were chosen according to two criteria: they needed to have been released during the last ten years and to have been played in cinemas in Lithuania. The scripts of the cartoon dialogues were obtained from the website www.veryabc.cn and were proofread for any discrepancies with the dialogues on DVD. The descriptive comparative analysis concentrates on the English language learning issues related with translation of idioms from English into Lithuanian, general translation problems, subtitle segmentation and breaking.

\section{Subtitling as a form of translation}

The history of subtitles in Europe dates back as early as 1929 when the first sound film, The Jazz Singer (released in the US in 1927), which enabled the viewers to hear the actors' dialogues, was shown with French subtitles in Paris (Ivarsson, 2004). Thus, subtitling is a comparatively new, yet rapidly developing branch of translation. According to Cintas (2007, p. 8), who are both a practitioner and a researcher of audiovisual translation, subtitling can be defined as:

a translation practice that consists of presenting a written text, generally on the lower part of the screen, that endeavours to recount the original dialogue of the speakers, as well as the discursive elements that appear in the image (letters, inserts, graffiti, inscriptions, placards and the like), and the information that is contained on the soundtrack (songs, voices).

Thus, subtitled audiovisual material demonstrates, with minor exceptions, the phenomenon of the change in language mode, from spoken to written. Also, it shows the interconnectedness of three different codes: textual, audio, and visual.

The specificity of subtitling lies in the fact that it is a rather constrained form of translation. Hatim and Mason in their article Politeness in Screen Translating (1997, pp. 430 - 431) distinguish four types of constraints that operate in the process of film subtitling:

- The already mentioned change of language mode from speech to writing, which results in the absence of such features of speech as dialect, intonation, 
etc. in the subtitles. It should be stressed, however, that some of these features can be retained with the help of punctuation marks and letter cases. For example, shouting or ordering is sometimes expressed in capital letters and through the extensive use of exclamation marks. Additionally, the visual images and the audio track help to understand such situations:

- Space and time constraint which means that only a certain number of symbols (usually up to 40) is allowed to be used in each of the two lines of subtitles. In addition, subtitles must follow the natural pace of the original dialogue.

- The compression of dialogue in order to fulfil the requirement mentioned above. The reduction of the original text puts certain pressure on the subtitler as only the secondary information can be omitted in order to retain the content of the film. Even though Szarkowska argues that "much of what is lost can be compensated for while hearing the original" (2005), the audience may not understand the source language $(\mathrm{SL})$, therefore, all the primary information is important to be presented in subtitles. In this case, the translator is the one to decide on the importance of the information presented in the film.

- The requirement of match between subtitle and image on the screen. That is to say, sometimes the original dialogue has to be modified according to, body language of the characters.

- Despite being a very specific form of translation in which the total correspondence of a SL dialogue with a target language (TL) subtitles is impossible in most cases due to the need of condensation, various studies show that subtitling can successfully be incorporated into the process of foreign language teaching and learning.

\section{Subtitles in foreign language teaching and learning contexts}

To deny the commonly expressed worries that subtitles require a lot of effort and distract the viewers' attention from both the images on the screen and the audio on the soundtrack, in this way causing the loss of original information, a number of studies prove that viewers manage to divide their attention between the two streams of information successfully (e.g. d'Ydewalle and Gielen, 1992). The analysis of different research related with the use of subtitles in foreign language teaching and learning shows that there are at least three ways to incorporate subtitling into this process.

Firstly, it is noticed that subtitled audiovisual material can be very beneficial in goal-oriented language classroom (Cintas and Cruz, 2008). According to eTwinning, which is a community for schools in Europe, the benefits of subtitles for language learners are as follows:

- Students can learn to process texts in the foreign language rapidly and improve rapid reading [...] 
- Students can learn how to pronounce many words [...].

- Learners can develop word recognition skills.

- Subtitles can help learners to acquire new vocabulary and idioms.

- Subtitles can motivate students to study foreign language outside the classroom context [...] (Arghir, n.d.).

It is worth mentioning that subtitled audiovisual material is in most cases carefully chosen by language teachers and is accompanied with pre and post tasks in order to enhance the effectiveness of the teaching and learning process. Some experimental studies indicate that students also receive specific training prior to the use of subtitled audiovisual material in the classroom in order to improve their linguistic achievements (e.g. Araujo, 2008). Thus, such teaching and learning method cannot replace the teacher as in such cases the teacher's role is as much (or even more) important as in ordinary classroom activities.

It should also be stressed that several modes of subtitles are possible to be used in order to enhance foreign language acquisition:

- Standard subtitling, when the audio information is presented in a foreign language (L2) while the subtitles are in a native language (L1) of the viewers. This mode is otherwise called interlingual subtitling.

- Reversed subtitling, when the audio information is presented in a native language (L1) while the subtitles are in a foreign language (L2) of the viewers.

- Bimodal subtitling, when both the audio information and the subtitles are presented in a foreign (L2) language of the viewers.

Interestingly, according to Cintas and Cruz (2008, p. 213), differently from standard subtitling, "reversed subtitling (at beginner and intermediate levels) and bimodal input (at intermediate and advanced levels) are very effective for the development of the main four linguistic skills".

The second method of incorporating subtitling into foreign language learning is through the very process of subtitling per se. Sokoli (2006) presents the Learning via Subtitling tool (LVS) "which is based on the simulation of a professional activity, that of film subtitling". The author states that such activities are combined of three language learning methods, namely, "the use of translation in the FL [foreign language] classroom", "the use of audiovisual material (video)" and "the use of Information and Communication Technologies" (ibid). Zanon points out that the focus on the "core of the utterance heard" rather than the effort to produce a faithful translation, the improvement in understanding "the internal coherence and cohesion of texts" and the "constant acquisition of vocabulary" (2005, p. 49) are among the most important benefits of this foreign language teaching and learning method. Thus, the limits of subtitling have now expanded from purely professional to amateur-educational practice.

Finally, interlingual standard subtitling, although not as effective as reversed or bimodal subtitling, is noted to be useful for incidental foreign language acquisition (i.e. when the primary aim of the person is not to learn the language) 
and confirmed by the statements that, for instance, "many Europeans claim to have learned English from their regular exposure to subtitled American films and television programs" (Danan, 2004, p. 67). Many Estonians, too, claim that subtitled TV programmes helped them in acquiring Finnish language. However, some researchers are of the opinion that the limited nature of subtitling and subtitlers' incompetence results in static and sometimes even poor subtitles which prevent the viewers from the opportunity to learn foreign idiomatic expressions, to understand jokes and cultural references (e.g. Baravykaite, 2007).

\section{Audiovisual translation in Lithuania}

Considering the traditions of audiovisual translation, Lithuania is mainly a voiceover country. Gottlieb (2001, p. 244) defines voice-over as an action when "[o]ne narrator interprets the lines of the entire cast (entire dialogue); the volume of the original sound is turned down while s/he is speaking". The majority of foreign films and programmes that are broadcasted on television are voiced-over in Lithuania with minor exceptions of Russian production, which is usually subtitled. However, the situation in cinemas is different as foreign films are subtitled with the exception of cartoons and feature films for children, which are dubbed (the original dialogue is replaced with a voice track of a target language). The same tendency is noticed in DVD sphere where the majority of films are subtitled except for the production for children which is slowly being replaced by dubbed versions.

According to the representatives of Lithuanian DVD distribution companies, dubbed cartoons on DVD are more popular than subtitled ones (Kapočiūtè, 2010). Yet, some parents note that their children tend to choose the subtitled versions of cartoons, since they are interested in hearing the original soundtrack with the attempt to try to understand the dialogue themselves (e.g. Pappel, personal communication). Also, it is often the case when parents buy subtitled cartoons for their children with the purpose of exposing the children to a foreign (usually English) language and in this way accelerating foreign language acquisition via entertainment (e.g. Mikšienè, personal communication). Moreover, cartoons on DVD are convenient for learning foreign languages, as they provide the opportunity of rewinding and repeating the same episodes for several times. However, a closer look at subtitled cartoons shows that not all cartoons are suitable for incidental foreign language learning due to certain translation and technical issues, which are discussed in greater detail in the following chapters.

\section{Subtitled idioms in children's cartoons}

Despite the fact that different researchers present different definitions of idioms, they are generally understood as phrases whose meaning "cannot be deduced from their individual components" (Baker, 1992, p. 63); their structure is usually fixed. The translation of idioms is a challenge, as many such phrases 
are culture-specific and have no equivalent in a TL. However, they are important to be retained in translation as they "serve emotive-expressive function" (my translation) and enrich the language (Jakaitiené, 1980, p. 112); thus, the matching of SL idiomatic expressions with TL expressions which perform equivalent functions could help children learn to increase the perception of stylistic devices and their usage as well as to enrich their mother tongue. Even though children's cartoons are full of idiomatic expressions, the expectations for subtitled cartoons to be a good source for children to learn idioms should be treated with care.

The analysis of the chosen cartoons shows the tendency of paraphrasing SL idioms in the Lithuanian subtitles and not retaining their stylistic functions (Table 1).

\section{Comparison of cartoons' subtitles and their translation}

Table 1

\begin{tabular}{|l|l|l|l|}
\hline \multicolumn{1}{|c|}{ English dialogue } & \multicolumn{1}{c|}{ Lithuanian subtitle } & \multicolumn{1}{c|}{ Back-translation } & \multicolumn{1}{c|}{ Cartoon } \\
\hline $\begin{array}{l}\text { I don't understand. } \\
\text { I know I heard you. } \\
\text { It was as plain as the } \\
\text { nose on my face. }\end{array}$ & $\begin{array}{l}\text { Nesuprantu. Juk tikrai } \\
\text { tave girdejau. // Tai } \\
\text { buvo akivaizdu. // }\end{array}$ & $\begin{array}{l}\text { I don't understand. } \\
\text { I heard you indeed. } \\
\text { It was obvious. }\end{array}$ & $\begin{array}{l}\text { Horton Hears } \\
\text { a Who }\end{array}$ \\
\hline
\end{tabular}

In example (1) the English idiom as plain as the nose on my face has a meaning of obvious. The Lithuanian subtitle presents only the denotative aspect (direct meaning) of the SL idiom, therefore, the stylistic function and the vividness of the original utterance is not revealed in the translation. It should be borne in mind that subtitlers are constrained by such technical requirements as 40 characters in a line, the match of subtitles and visuals on the screen and the like. Yet, in this case the English idiom has the Lithuanian equivalent aiškiai kaip dieną (En. as clear as in a daytime) which performs the same stylistic function as the SL idiom and which could have been used instead of the whole sentence Tai buvo akivaizdu without increasing the number of characters in the subtitle.

In addition to the reduction of stylistic functions, there also appear cases of idiom mistranslation (Table 2.).

Table 2

\section{Comparison of cartoons' subtitles and their translation}

\begin{tabular}{|c|c|c|c|}
\hline English dialogue & Lithuanian subtitle & Back-translation & Cartoon \\
\hline $\begin{array}{l}\text { For centuries, we've } \\
\text { watched our brethren } \\
\text { perish at the claw of } \\
\text { the lion. Today, we put } \\
\text { our hooves down. No } \\
\text { longer will we dwell at } \\
\text { the bottom of the food } \\
\text { chain. }\end{array}$ & $\begin{array}{l}\text { Daug amžiu stebėjome // } \\
\text { kaip mūsu broliai // } \\
\text { kenčia nuo liūto letenos. } \\
\text { // Šiandien mes trepsim } \\
\text { kanopom. // Užteks } \\
\text { būti maisto // grandinès } \\
\text { apačioje. // }\end{array}$ & $\begin{array}{l}\text { For many centuries } \\
\text { we've watched our } \\
\text { brothers suffer from } \\
\text { the claw of the lion. } \\
\text { Today we're stamping } \\
\text { our hooves. Enough } \\
\text { of being at the bottom } \\
\text { of the food chain. }\end{array}$ & The Wild \\
\hline
\end{tabular}


In this episode of the cartoon the leader of a group of wildebeests expresses his intention to catch the lion character and kill him in revenge. Although the wildebeest stamps down his hoof as he exclaims Today, we put our hooves down, the utterance is a transformation of the idiom to put one's foot down, which expresses objection. Thus, the literal translation in the Lithuanian subtitle changes the denotative meaning of the SL idiom, since the Lithuanian translation refers to the mere physical action of stamping the hoof.

It should also be noted that some idioms can function as wordplay, which makes them even more problematic to be transferred in a TL subtitles, for instance:

Comparison of cartoons' subtitles and their translation

Table 3

\begin{tabular}{|l|l|l|l|}
\hline \multicolumn{1}{|c|}{ English dialogue } & \multicolumn{1}{c|}{ Lithuanian subtitle } & \multicolumn{1}{c|}{ Back-translation } & Cartoon \\
\hline - Come on, baby, sing it! & - Na, mieloji, dainuok! // & - Come on, baby, sing it! & Rio \\
- And when she passes, & - Kiekvienas praeivis // & - Each passerby looks at & \\
each one she passes & lydi ja susižavejjimo & her in admiration, ah! & \\
goes, ah! & žvilgsniu, ah!// & - Like a river of the & \\
- Like a river of the & - Kaip saldžiausio medaus & sweetest honey. \\
sweetest honey. & upè.// & - I guess love is blind. & \\
- I guess love is deaf, & - Tikriausiai meilè akla. // & & \\
too. & & & \\
\hline
\end{tabular}

In this scene the bird character toucan Rafael tells the two Macau parrot characters about the first time he met his wife and asks his wife to sing. As it appears that she is not a good singer, one of the Macau parrots expresses her surprise using the idiom love is deaf, which is the transformed version of love is blind idiom. Thus, referring to the fact of bad singing, the idiom love is deaf functions as wordplay. Despite that, the wordplay is not retained in the Lithuanian subtitle, as the translation does not indicate the transformation of the SL idiom. Considering the fact that the English idiom love is blind has its established and widely used equivalent meile akla in the Lithuanian language, the transformed version meile kurčia (En. love is deaf) would perform the equivalent function in the TL subtitle. Bearing in mind the space constraint in subtitling, the Lithuanian word tikriausiai is possible to be replaced with the synonym turbūt in order to save space for the longer word kurčia (two characters longer than the word akla) in order to retain the wordplay. The cases of mistranslation and the loss of wordplay, however, are bound not only to the sphere of idioms, but may be treated as translation problems in general.

\section{General translation problems}

Apart from idiom translation issues, general translation problems related with denotative equivalence are also noticed in the Lithuanian subtitles of the cartoons (Table 4). 
Table 4

Comparison of cartoons' subtitles and their translation

\begin{tabular}{|c|c|c|c|}
\hline English dialogue & Lithuanian subtitle & Back-translation & Cartoon \\
\hline $\begin{array}{r}\text { - Gummy worm, } \\
\text { anybody? }\end{array}$ & $\begin{array}{r}\text { - Guminis sliekas, ar } \\
\text { kažkas? // }\end{array}$ & $\begin{array}{r}\text { - Gummy worm or } \\
\text { somebody? }\end{array}$ & Over the Hedge \\
\hline The show is starting. & Pradejo snigti. // & It's started snowing. & Over the Hedge \\
\hline
\end{tabular}

Example (4) shows that certain incongruities between the SL dialogues and the TL subtitles can be found. The first SL utterance functions as an offer, nevertheless, it becomes a phrase of hesitation in the Lithuanian subtitle. In the second utterance the SL word show is changed into the word snow in the TL subtitle. This might be influenced by the fact that subtitlers sometimes have to work without scripts relying only on their listening comprehension. Yet, the context of this episode clearly shows that the characters are sitting in front of a TV and are going to watch some TV show. Such discrepancies are hazardous in the context of incidental foreign language acquisition, as the learner is in danger of acquiring wrong TL equivalents for the SL words and utterances.

\section{Segmentation and line breaking}

One more issue related to the use of subtitled cartoons for foreign language learning is segmentation and line breaking. Cintas \& Remael define segmentation as "the division of the ST [source text] dialogue, narration, etc. into sections or segments subtitles - that the viewers can understand at a glance" (2007, p. 172). They also note that there might be two types of segmentation, namely, "[a] sentence may have to be distributed over the two available lines of a subtitle - line breaks - or it may run on, into two or more subtitles" (ibid). It has to be highlighted that correct segmentation and line breaking are very important in subtitling, as subtitles appear on the screen for a very short time and therefore need to be as comprehensible as possible. For this reason, in two-line subtitles the syntactic and grammatical matters get preference over the aesthetics (e.g. subtitle layout) (ibid).

In the context of incidental foreign language learning, correct segmentation and line breaking are also very important, as incomprehensible subtitles will slow down reading and leave less or no time for language acquisition process, as all the viewers' efforts will be devoted to the reading process. However, some cartoons perform especially poor segmentation and line breaking (Table 5).

As example (5) shows, each of the Lithuanian subtitles consists of two clauses which are separated with a comma. Ideally, one subtitle should contain one sentence; however, in this case it is not possible as the maximum number of characters in a subtitle would be exceeded. In such case, according to Cintas and Remael, one line of a subtitle should contain one clause (2007, p. 176). Thus, a more comprehensible version of the subtitles presented in example (5) would be as follows (Table 6). 


\section{Segmentation and line breaking in Lithuanian subtitles}

Table 5

\begin{tabular}{|l|l|l|c|}
\hline \multicolumn{1}{|c|}{ English dialogue } & \multicolumn{1}{|c|}{ Lithuanian subtitle } & \multicolumn{1}{c|}{ Back-translation } & Cartoon \\
\hline $\begin{array}{l}\text { Also, I got a couple of } \\
\text { reports of root beer } \\
\text { being poured on us. }\end{array}$ & $\begin{array}{l}\text { Taip pat man pranešè, } \\
\text { kad // } \\
\text { ant bičiu buvo užpilta } \\
\text { alaus. // }\end{array}$ & $\begin{array}{l}\text { Also, I was informed that } \\
\text { beer was poured on the bees. }\end{array}$ & Bee Movie \\
\hline $\begin{array}{l}\text { - Did they try to kill } \\
\text { you, like on TV? }\end{array}$ & $\begin{array}{l}\text { - Ar jie mégino tave } \\
\text { nužudyti, kaip per // } \\
\text { teliką rodo? }\end{array}$ & $\begin{array}{l}\text { - Did they try to kill you, like } \\
\text { it is shown on TV? }\end{array}$ & Bee Movie \\
\hline
\end{tabular}

Segmentation and line breaking in Lithuanian subtitles

Table 6

$$
\text { Lithuanian subtitle }
$$

Taip pat man pranešè, // kad ant bičiu buvo užpilta alaus. //

- Ar jie mègino tave nužudyti, // kaip per teliką rodo? //

In addition, there also appear cases when line breaking is used for short subtitles (Table 7).

Table 7

\section{Segmentation and line breaking in Lithuanian subtitles}

\begin{tabular}{|l|l|l|c|}
\hline \multicolumn{1}{|c|}{ English dialogue } & \multicolumn{1}{c|}{ Lithuanian subtitle } & \multicolumn{1}{c|}{ Back-translation } & Cartoon \\
\hline $\begin{array}{l}\text { You grab that stick, } \\
\text { and you just move it } \\
\text { around, and you stir it } \\
\text { around. }\end{array}$ & $\begin{array}{l}\text { Čiumpi pagali ir// } \\
\text { suki, suki. // }\end{array}$ & $\begin{array}{l}\text { You grab the stick and } \\
\text { move it around, move it } \\
\text { around. }\end{array}$ & Bee Movie \\
\hline $\begin{array}{l}\text { You know, Dad, the } \\
\text { more I think about it, } \\
\text { maybe the honey field } \\
\text { just isn't right for me. }\end{array}$ & $\begin{array}{l}\text { Kuo // daugiau galvoju, // } \\
\text { tuo labiau manau, // } \\
\text { kad medaus sritis manęs } \\
\text { nevilioja. // }\end{array}$ & $\begin{array}{l}\text { The more I think about } \\
\text { it, the more I realise that } \\
\text { honey sphere doesn't } \\
\text { attract me }\end{array}$ & Bee Movie \\
\hline
\end{tabular}

Despite the fact that the subtitler in this example succeeds in condensing the original dialogue, the line breaking is used improperly. The first and the second subtitles consist of 28 and 38 characters respectively; therefore, there is no need to break the lines as the text in each case fits into one-line subtitle without exceeding the maximum number of characters.

\section{Conclusions}

To sum up, subtitled audiovisual material as well as the very process of subtitling is found to be beneficial in foreign language teaching and learning classroom. Moreover, despite some negative opinions, subtitled audiovisual programmes and films are considered to be useful for incidental foreign language acquisition. 
Yet, having analysed seven cartoons with relation to children's incidental English language learning through subtitled cartoons on DVD in Lithuania, the following aspects should be outlined:

- not all idiomatic SL expressions retain their idiomatic aspect in the Lithuanian subtitles, even in the cases when such retention is possible; cases of idiom mistranslation and the loss of wordplay are noticed. All of these points may diminish the childrens' perception of the idiom, cause the danger of acquiring incorrect Lithuanian equivalents for the English language idiomatic expressions and impoverish the mother tongue.

- cases of inaccurate translation in general, due to the process of the matching of the $S L$ audio with the TL text, may result in the already mentioned acquisition of incorrect TL equivalents;

- errors in segmentation and line breaking may diminish the process of foreign language acquisition by slowing down the reading process.

The findings of the study are not aimed at refuting the fact that subtitled cartoons on DVD are beneficial for incidental foreign language learning. Rather, they are aimed at showing that a high quality of subtitling is essential and, therefore, not every children's cartoon can fulfill the goal of foreign language acquisition.

\section{References}

Araujo, V. L. S. (2008). The educational use of subtitled films in EFL teaching. In Cintas, J. D. (Ed.) The Didactics of Audiovisual Translation (pp. 227 - 238). Amsterdam/Philadelphia: John Benjamins Publishing Company.

Arghir, D. (n.d.). Subtitling tools: Great for eTwinning videos. In eTwinning. Retrieved from http://www.etwinning.net/en/pub/collaborate/modules/ subtitling_tools_ great_for_et.htm.

Baker, M. (1992). In Other Words. London and New York: Routledge.

Baravykaitè, A. (2007). Kino filmu titrai kaip kalbu mokymosi priemonè. Kalbotyra, $57(3), 21-29$.

Cintas, J. D. \& Cruz, M. F. (2008). Using subtitled video materials for foreign language instruction. In Cintas, J. D. (Ed.) The Didactics of Audiovisual Translation (pp. 201 - 214). Amsterdam/Philadelphia: John Benjamins Publishing Company.

Cintas, J. D. \& Remael. A. (2007) Audiovisual translation: Subtitling. Manchester: St. Jerome Publishing.

d'Ydewalle, G. \& Gielen, I. (1992). Attention allocation with overlapping sound, image, and text. In Reiner, K. (Ed.). Eye Movements and Visual Cognition. Scene Perception and Reading (pp. 415 - 427). New York: Springer-Verlag.

Danan, M. (2004). Captioning and subtitling: Undervalued language learning strategies. Meta: Translator's Journal, 49, 67 - 77. doi:10.7202/009021ar.

Gottlieb, H. (2001). Subtitling. In Baker, M. (Ed.). Routledge Encyclopedia of Translation Studies. London and New York: Routledge.

Hatim, B. \& Mason, I. (1997) Politeness in screen translating. In Venuti, L. (Ed.). The Translation Studies Reader (pp. 433 - 445). London and New York: Routledge. 
Ivarrson, J. (2004). A Short Technical History of Subtitles in Europe. TransEdit. Retrieved from http://www.transedit.se/history.htm.

Jakaitienè, E. (1980). Lietuviu kalbos leksikologija. Vilnius: Mokslas.

Kapočiūtè, E. (2010, November 29). Lietuvos žinios. Retrieved from http://www.Izinios.It/Verslas/Kinas-parduodamas-vis-geriau.

Movie English. Retrieved from http://www.veryabc.cn.

Sokoli, S. (2006). Learning via Subtitling (LvS): A tool for the creation of foreign language learning activities based on film subtitling. In Multidimentional Translation - MuTra. Retrieved from http://www.euroconferences.info/proceedings/2006 Proceedings/2006_Sokoli_Stravoula.pdf.

Szarkowska, A. (2005). The Power of Film Translation. Translation Journal. Retrieved from http://accurapid.com/journal/32film.htm.

Subtitles and Language Learning. Retrieved from http://www.sublanglearn.utu.fi.

Talaván Zanón, N. (2006). Using subtitles to enhance foreign language learning. Porta Linguarum, 6, $41-52$.

\section{Cartoons}

Anderson, B. \& Donkin, J. C. (Producers) and Saldanha, C. (Director). (2011). Rio [Animated movie]. USA: Blue Sky Studios.

Anderson, B. \& Gordon, B. (Producers) and Hayward, J. \& Martino, S. (Directors). (2008). Horton Hears a Who [Animated movie]. USA: Twentieth Century Fox Animation.

Arnold, B. (Producer) and Johnson, T. \& Kirkpatrick, K. (Directors). (2006). Over the Hedge [Animated movie]. USA: DreamWorks Animation.

Goldman, C. (Producer) and Williams, S. (Director). (2006). The Wild [Animated movie]. USA: Walt Disney Pictures.

Lewis, B. (Producer) and Bird, B. (Director). (2007). Ratatouille [Animated movie]. United States: Pixar Animation Studios.

Seinfeld, J. \& Steinberg, C. (Producers) and Hickner, S. \& Smith, S. J. (Directors). (2007). Bee Movie [Animated movie]. USA: DreamWorks Animation.

Williams, J. H. (Producer) and Chapman, G. (Director). (2005). Valiant [Animated movie]. UK: Buena Vista Home Entertainment.

\section{LIGITA JUDICKAITĖ-PAŠVENSKIENĖ}

Vytauto Didžiojo universitetas

\section{SUBTITRUOTI ANIMACINIAI FILMAI UŽSIENIO KALBOS MOKYMO IR MOKYMOSI KONTEKSTE: GALIMI PAVOJAI}

Santrauka. Užsienio kalbos mokymas ir mokymasis pavirto daugialypiu procesu, i kuri itraukiama ne tik rašytinè ar garso, bet ir vaizdo, vaizdo-garso, subtitruota vaizdo-garso ir kitokia medžiaga. Daugelyje tyrimu atskleidžiama subtitruotos vaizdinès-garsinès medžiagos bei paties subtitravimo proceso nauda užsienio kalbos mokymo ir mokymosi kontekste. 
Straipsnio tikslai - pristatyti subtitravima kaip viena iš vertimo šaku ir jo naudojima kalbos mokymui bei mokymuisi; aptarti galimus pavojus, kai atsitiktinio kalbos mokymosi procese naudojami subtitruoti animaciniai filmai vaikams (Lietuvos atvejo analizè). Straipsnyje pateikiama septyniu animaciniu filmu ("Sparnuotasis desantas", "Laukiniai nuotykiai", "Anapus tvoros", "La troškinys", "Bitès filmas", "Hortonas" ir "Rio") dialogu bei ju lietuvišku subtitru aprašomoji-lyginamoji analizė, orientuota i anglišku frazeologizmu vertima i lietuviu kalba, bendrąsias vertimo problemas bei subtitru segmentavimą ir eilučiu laužymą.

Tyrimo rezultatai rodo, kad ne visu originalo kalbos frazeologizmu idiomatinè reikšmè perteikiama vertimu (netgi tada, kai tai imanoma). Taip pat randama netikslaus vertimo atveju bei subtitru segmentavimo ir eilučiu laužymo klaidu. Visa tai gali skurdinti vaiku gimtaja kalba ir kliudyti sklandžiai mokytis užsienio kalbos iš subtitru. Tyrimo rezultatais nenorima sumenkinti subtitruotu animaciniu filmu vaikams DVD formatu vertès atsitiktinio kalbos mokymosi kontekste. Priešingai, norima parodyti, jog kalbos mokymuisi būtina gera vertimo kokybè ir ne kiekvienas animacinis filmas tinka mokytis užsienio kalbos.

Pagrindinès sąvokos: subtitrai, animaciniai filmai, užsienio kalbos mokymas ir mokymasis, idiomos. 